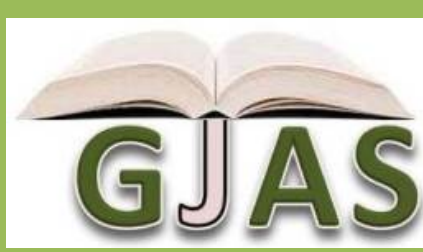

\title{
Determinants of Agricultural Performance of Supported Vulnerable Households in Zimbabwe
}

\section{Jackqeline Mutambara* and Charity Mumaniki}

University of Zimbabwe, Faculty of Agriculture, Department of Agricultural Economics and Extension, Box MP 167, Mount Pleasant, Harare, Zimbabwe

Article No.: 061213668

DOI: 10.15580/GJAS.2013.8.061213668

Submitted: 12/06/2013

Accepted: 22/08/2013

Published: 29/08/2013

${ }^{*}$ Corresponding Author

Jackqeline Mutambara

E-mail: jmutambara@

agric.uz.ac.zw, jmuzenda@

yahoo.co.uk

Keywords:

Seeds, Fertilizer, Descriptive,

Correlation, Education, Extension,

Implements, Livestock,

Chronically, III
The study looked at the determinants of performance of donated seeds and fertilizers packs in maize production by HIV and AIDS affected households. Primary data collected by the researcher and secondary data collected from FAO were used for analysis. Descriptive statistics and correlation analysis were tools employed for data analysis in trying to come out with the determinants of productivity of vulnerable households who received input donations in the form of maize seed and fertilizers. From the results, socioeconomic variables such as access to extension (0.4), level of education attained by member (0.3), possession of farming implement [(hoes (0.4) and ploughs (0.4)] and livestock (0.7) have shown to determine positively and significantly to the productivity of supported vulnerable families. The number of chronically ill members of the household had an inverse $(-0.4)$ relationship to productivity of vulnerable families. The study thus concludes that targeting on input packages should focus on well resourced (education, extension, implements and livestock) HIV and AIDS affected households while households under severe illnesses should be targets for humanitarian assistance as they cannot productively utilize supplied inputs due to demanding circumstances in the family. 


\section{INTRODUCTION}

Zimbabwe is one of the countries among other subSaharan countries that are experiencing terrible loss of labor and skills through HIV and AIDS, (FAO, 2006). The prevalence rate is estimated at $14.5 \%$ with around one in ten of the population with HIV. Infant mortality rate has doubled since 1990, average life expectancy for women affected by the AIDS pandemic is 47.6 years. Across countries in the eastern and southern Africa HIV prevalence rates are among the highest in the world, with rates as high as $24 \%$ and as low as $5 \%$ in Uganda, (Brent 2003). Zimbabwe has a high number of orphans in proportion to its population of her country, as one in every four children (24\%) in Zimbabwe are orphaned and this is mainly attributable to parents dying of AIDS. (ZIMSTAT, 2009).

More than 60 percent of people in Zimbabwe reside in rural areas and depend on rain fed smallholder agriculture as the main source of livelihood (Rukuni, 2006). HIV/AIDS affects more households through its impact on the availability of these assets that are required to undertake agricultural production, the household's ability to generate income and the ability of social support system to meet the household's needs. Stigmatization due to infection can limit social linkages and networks (for example family and community members), thus limiting access to resources (Van Lierre, 2002).

FAO studies done in Southern Africa indicate evidence that poor households incur debt in order to meet additional health costs, funeral expenses, amid other immediate expenses. They try to hold on productive assets such as land, farming implements and trees for as long as possible (Kwaramba, 1997). Eventually households are forced to sell livestock including draught animals (cattle and donkeys) and sell farm implements such as ploughs, cultivators, scotchcarts and wheelbarrows. Sale of productive assets such as draft power animals and agricultural implements jeopardizes the agricultural production capability of the household, impairing future productivity.

The widespread loss of active adults disrupts mechanisms for transferring indigenous farming methods, knowledge, values and beliefs from one generation to the next. This has serious implications on agricultural and livestock production. In Swaziland, a study on the impacts of HIV/AIDS and drought on local knowledge confirmed that the pandemic erodes gendered-local knowledge. Death of the man usually means the disappearance of knowledge and skills related to maize and cotton production, whereas the death of the woman affects the household's knowledge on legume production (Drimmie, 2002). The burden of the care of sick adults might cause productive duties to be neglected or children to be taken out of school. In most cases many orphans are not taken in by extended families and thus burdened with adult responsibilities, such as putting food on the table, long before they ought to be (Barks-Ruggles, 2001).

According to the UN Secretary General's Task Force Report on Women, Girls and HIV/AIDS in Zimbabwe (2004), as the death toll from AIDS is mounting, many widowed women are experiencing dispossessions of land in rural areas. Women often do not have marriage certificates or other documentation to protect their rights (and wills are rarely drawn up). A study by Brent et al. (2003) in Namibia revealed that households where husbands had died of HIV/AIDSrelated illnesses are disadvantaged. The traditional practice of taking land away from the widow and children continued and, in extreme cases, their livestock are also taken.

This adds on to Kwaramba's findings in 1997 that workload is increased among women and this impact negatively on agricultural production and food security. He further urges that in communities where there is a traditional division of labor by gender between agricultural and household work, women have to take up additional burden of taking care of the sick, orphans and attend frequent funerals. The increased workload may greatly reduce their time to participate in agricultural activities, leading to a decline in agricultural production. Affected households, and in particular female-headed households, reduces the total area under cultivation due to labor shortages (Kwaramba, 1997). The study by Ncube (1999) revealed a decline in area under crop cultivation for AIDS affected households because of HIV/AIDS related reasons which include; shortage of labor, lack of inputs as the provider had died, and lack of draft power and farm implements as they were sold to cover medical and funeral expenses.

In a study of 1422 rural households in Kenya, Yamano et al. (2002) found that the total area under cultivation decreased by $26 \%$ if the head of household died. Besides the decline in crop acreage, AIDS affected households also experience declines in crop yield because of poor management of the crops. The overall result of the preceding impacts of HIV/AIDS is a decline in agriculture production. Decreased agricultural production impacts negatively on household food security and general livelihood.

Due to these shocks and stresses, HIV/AIDS affected households among other vulnerable households are left without the necessary inputs to restart farming, (ZIMVAC, 2010). Thus agricultural recovery programs are implemented by central governments and NGOs with increased vigor to capacitate smallholder farmers against food insecurity. Input aid in the form of fertilizer and seed aid to HIV/AIDS affected households has the following broad objectives:

- To reduce the cost of producing the staple crop and other crop yields of agriculture dependant households

- To reduce food insecurity and dependency on food aid 
- To help food insecure farmers increase agricultural productivity and achieve food security through increased food and pulse production yield hence livelihood

- To transfer improved seed varieties and fertilizers to farmers

- To stimulate 'progressive modern farming practices'. Progressive farmers are those with precious irrigated plots and are targeted with hybrid maize and income-generating vegetable seeds (Rohr et al., 2004).

Non-governmental organizations which include Care International, World Vision and Citizens Network for Foreign Affairs have contributed to improved fertilizer use by training and establishing agro-dealers in smallholder areas. In the smallholder farming sector, the supply of inputs is mainly through general dealers and small agro-dealers thus investment in improved private marketing infrastructure in rural areas seems to be one of the most promising roles for the state (Rusike, 1997).

Although, past studies have noted that the main determinant of the size of the area planted and increased yields to key crops is the ownership of draft power (Rorh et al., 2004). The distribution of fertilizer to vulnerable families enhances productivity and consequently improves prospects for an improvement in the food security of the vulnerable households. According to ICRISAT (2004), fertilizer offered an average of 60 percent yield gain to maize, almost every farmer who applied this input received a positive yield. Despite the variability of rainfall, the contribution of the chemical fertilizer to the improvement of maize yields was substantial.

An upper estimate of the contribution of the relief seed to household production and food security can be derived from available estimates of the area planted to fertilizer and seed donations and mean yields obtained assuming that the recipients of these inputs would not have obtained any seed from alternative sources. Instead, they would simply have planted less land at all if they truly had no seed stocks. According to Maramanyika (2008), provision of crop packs enabled $89 \%$ of the farmers to increase their land under cultivation. This research therefore seeks to verify the factors that affect efficacy of the crop input donations to the HIV and AIDS affected dependants in Zimbabwe in an effort to confront the epidemic through improving the livelihoods and food security. The outcomes from this study will help in targeting vulnerable households who can make productive use of supplied resources.

\section{MATERIALS AND METHODS}

\section{The study area}

This research was carried out in Tatonga Wards 1 and 2 in Chirumanzu District, Midlands Province which lies in
Natural Farming Region 3. Inhabitants of this area survive mainly through the cultivation of crops such as maize, groundnuts and rapoko. Chirumanzu is characterized mainly by sand and clay soils with some very few portions covered with loam soils and this requires large amounts of fertilizers to boost production. Due to high costs of inputs such as seed and fertilizers and unavailability of labor, some HIV and AIDS affected households among other vulnerable households have not been able to meet costs thereby leaving the fields uncultivated. This has attracted the attention of various organizations such as Care International, CADEC and Oxfam now embarking on input donations in the area in the form of chemical fertilizers, maize and groundnut seeds.

\section{Sample size selection}

This research focused on vulnerable households affected and infected with HIV and AIDS. The sample was drawn from a list of individuals who have joined Tatonga Home Based Care Program (THBCP) after testing positive for HIV virus and undergone counseling. The households ranged from child-headed to singleheaded families and their occupation were mainly through small scale farming in Chirumanzu district.

A list of household heads was collected from THBCP. This program consisted of 365 families. Of the 365 families, 200 families have received input assistance with the notion that when NGOs target population for receipt of input assistance, $60 \%$ of the poorest and $60 \%$ of the wealthiest are targeted leaving out some vulnerable households. A cross section of HIV/AIDS affected households that have received input assistance was made and 101 households were randomly selected.

\section{Data analysis and processing}

In this study, descriptive statistics and correlation analysis were used to ascertain the determinants of performance of supported households.

\section{RESULTS}

\section{General characteristics of respondents}

Sex: Only $39 \%(\mathrm{~N}=101)$ of the households heads were males while $61 \%$ of the households heads were females and this outcome emphasizes the dominance of females among vulnerable households.

Marital Status: The majority of household heads were widowed/widower $(69 \%)$, with more widows $(49 \%)$ than widowers $(20 \%)$. About $13 \%$ were unmarried household heads mainly composed of children and $18 \%$ were married (Table 1). 
Table 1: Sex and marital status of key household member

\begin{tabular}{|l|l|l|l|l|l|}
\hline Marital Status & Males & Females & Total \\
\hline & Frequency & Percent & Frequency & Percent & \\
\hline Married or living together & 12 & $12 \%$ & 6 & $6 \%$ & $18 \%$ \\
\hline Never married including orphans & 7 & $7 \%$ & 6 & $6 \%$ & $13 \%$ \\
\hline Widowed/widower & 20 & $20 \%$ & 49 & $49 \%$ & $69 \%$ \\
\hline Total & 39 & $39 \%$ & 61 & $61 \%$ & $100 \%$ \\
\hline
\end{tabular}

Source: survey data

Education : About $44 \%$ of the household heads had secondary education, $38 \%$ primary education, $12 \%$ tertiary education and the remainder with no education at all (Table 2).

Table 2: Highest level of education attained by household head

\begin{tabular}{|l|l|l|}
\hline Education Level & Frequency & Percent \\
\hline No education & 7 & $6.9 \%$ \\
\hline Primary level & 38 & $37 \%$ \\
\hline Secondary level & 44 & $44 \%$ \\
\hline Tertiary level & 12 & $12 \%$ \\
\hline Total & 101 & $100 \%$ \\
\hline
\end{tabular}

Source: survey data

\section{Farming Practices}

Maize cropping area over time: Table 3 shows the size of land under maize in both seasons of 2004/05 and $2009 / 10$. The majority of the households, comprising of $47.5 \%$ cultivated a total area of less than one hectare in $2004 / 2005$ season compared to Only $32 \%$ in $2009 / 10$ season indicating a reduction of households using less than one hectare in maize production. About $27 \%$ cultivated between 2-3 hectares of maize in 2004/05 season while $36 \%$ were in the same range in 2009/10 season indicating an increase is area of maize cropped in this range. Maize area of over 3 hectares was attained by only $25 \%$ in $2004 / 05$ season compared to $32 \%$ in 2009/10 season (Table 4).

Table 4: Total size of land cultivated under maize in both seasons

\begin{tabular}{|l|l|l|l|l|}
\hline Hectares & \multicolumn{2}{|l|}{ 2004/05 cropping season } & \multicolumn{2}{l|}{ 2009/10 cropping } \\
\hline & Frequency & Percent & Frequency & Percent \\
\hline$<1$ hectare & 48 & 47.5 & 32 & 32 \\
\hline $1-2$ hectare & 27 & 26.7 & 36 & 36 \\
\hline$>2$ hectare & 26 & 24.7 & 33 & 32 \\
\hline Total & 101 & 100 & 101 & 100 \\
\hline
\end{tabular}

Source: survey data

Procurement of inputs: Table 5 show input sources and usage for the 2009/10 cropping seasons. From the table, the great majority of the donated seed was sown and households would leave an average of $4.4 \mathrm{~kg}$ for the next season which is even more than the quantity retained from the last season. Seventy percent of top dressing fertilizer donated was applied; whereas, basal fertilizers applied were far below the mean quantities donated. This was mainly attributed to the late arrival of this input.

Table 5: Input sources and usage (mean quantities in kgs)

\begin{tabular}{|c|c|c|c|c|c|}
\hline Input (kgs) & \multicolumn{3}{|c|}{ Source } & \multicolumn{2}{|l|}{ Use } \\
\hline & Bought & Retained from last season & Donated & Planted/Applied & Remaining \\
\hline Maize seed & 9.8 & 1.1 & 12.9 & 22.4 & 4.4 \\
\hline AN & 55 & 5 & 76 & 59.3 & 14.5 \\
\hline Compound D & 20.1 & - & 35.2 & 24.9 & 36.6 \\
\hline
\end{tabular}

Source: survey data 
Input donations: Farmers received input donations packs from various organizations such as OXFAM, CARE and MASSO and each organization was offering a standard package of inputs as indicated in Table 6.

Table 6: Input donations (mean quantities in kgs) for 2009/10 season

\begin{tabular}{|l|l|l|l|}
\hline Donor & Received (kgs) & Planted/applied (kgs) & Remaining (kgs) \\
\hline OXFAM seed & 10 & 8 & 2 \\
AN & 100 & 89.2 & 10 \\
D & 25 & 10 & 15 \\
\hline CARE seed & 15 & 10 & 5 \\
AN & 70 & 65.3 & 5.9 \\
D & 20 & 20 & - \\
\hline MASSO seed & 12 & 11.2 & 0.8 \\
AN & 50 & 50 & - \\
D & 50 & - & 50 \\
\hline
\end{tabular}

Yield in maize production: The average yield of supported households was 2.1 tonnes per hectare which was higher than pre-intervention of 1.6 tonnes per hectare.

\section{Determinants of performance of supported households}

In order to see the complementarities of various socioeconomic characteristics of households to donated households on yields for the 2009/10 season, yield levels for that year were used as dependant variable and correlations of various independent variables were observed as shown in the Table 9.

Table 9: Relationship between yields and socio-economic factors of supported farmers.

\begin{tabular}{|l|l|l|}
\hline Socioeconomic variable & Correlation coefficient & Significance \\
\hline Age & 0.249 & 0.079 \\
\hline Sex & 0.082 & 0.699 \\
\hline Household size & -0.152 & 0.767 \\
\hline Number of chronically ill adults & -0.402 & $0.000^{* * \star}$ \\
\hline Education level & 0.299 & $0.032^{* \star}$ \\
\hline Access to extension & 0.361 & $0.002^{* *}$ \\
\hline Number of hoes possessed & 0.420 & $0.000^{* * \star}$ \\
\hline Number of cattle owned & 0.646 & $0.000^{* * *}$ \\
\hline Number of ploughs owned & 0.420 & $0.000^{* * \star}$ \\
${ }^{* *}$ significance at 5\% level, ${ }^{* *}$ significance at 1\% level \\
Source: Survey data
\end{tabular}

The correlations of several factors in the table above are significant at the $1 \%$ level in determining a household productivity status. The greater the correlation coefficient between the factors, the more this combination determines maize yield levels. The ownership of draught power has positive (0.7) significant contribution to the performance of supported farmers. Results also indicate that number of chronically ill adults within a household correlates negatively $(-0.4)$ with household productivity. Other socioeconomic variables such as access to extension, level of education attained by member and possession of farming implement have shown to determine positively and significantly to productivity of supported vulnerable families with coefficients $0.4,0.3$ and 0.4 respectively.

\section{DISCUSSION}

Determinants of performance of supported families 
Variables considered in the model as independent variables include sex, the level of education attained by the key household member, total number of members and chronically ill adult members within a household. Total number of assets, access to extension and livestock ownership were also treated as independent variables. The dependent variable was maize yields for 2009/10 cropping season. Household size and number of chronically ill members within a household were also considered to be correlated to maize yields. Of these variables, sex, household size and age of key household member did not have significant positive correlation. The correlation coefficients for these variables were $0.089,0.249$ and -0.159 respectively, implying a weak correlation among these variables with output. Sex and age of key household member do not determine productivity, therefore their significance was compromised. Number of chronically ill members within a household was significantly correlated negatively to household productivity. This is because illness of member results in insufficient labor required for farming or leading to diversion of labor to care for the sick. Even if farmers receive inputs to increase productivity, without enough labor production will not be enhanced.

Total number of assets, livestock, education level and access to extension services showed a significant positive correlation with maize yields of input beneficiaries. The ownership of ploughs, hoes and cattle enhance productivity, they determine the area under crop cultivation. With the advent of input donations, highly endowed households tend to increase the area under crop cultivation and have the capacity to increase yields.

Access to extension and level of education attained by a key household member is highly correlated to maize yields. Households with access to extension services benefit more from input donations because they are equipped with technical experience and skills from extension workers. They adhere to instructions and have the ability to grasp concepts fast; they are also flexible to adjust to stress factors particularly climate change. The positive relationship between maize yields and ownership of productive resources such as draft and mechanical asset ownership and negative correlation portrayed by number of chronically ill adults as limitation to labor availability.

The study has evidence to prove that crop packs (input donations) should be targeted to well endowed HIV and AIDs affected households who are capable of increasing the total quantity of crop harvested; these households would then assist poorer households. Humanitarian assistance can also be targeted to households under severe illnesses as they cannot productively utilize supplied inputs due to demanding circumstances in the family.

\section{REFERENCES}

Barks-Ruggles. (2001). Meeting the global challenges of HIV/AIDS (unpublished)

Brent, R.J. (2003). Cost-Benefit Analysis and Health Care Evaluations, Massachusetts: Edward Elgar Publishing Company.

Drimmie, S. (2002). The Impact of HIV/AIDS and Agriculture in Southern Africa: What difference does it make? IDS Bulletin, Volume 36, Number 2.

Food and Agricultural Organizations in Zimbabwe (F.A.O), (2006). Fertilizer use by crops in Zimbabwe; Land and Plant Nutrition Management Service and Water Development Division: FAO of the United Nations Publications, Rome.

ICRISAT Zimbabwe. (2006). Building Sustainable Fertilizer Delivery Systems for Drought Prone Regions, ICRISAT publications, Harare.

Muir K., (2004). Agriculture in Zimbabwe. In Zimbabwe's Agricultural Revolution (Revised) Edited By Rukuni M, Tawonezvi P, Eicher $\mathrm{C}$ with Hungwe $\mathrm{M} M$ and Matondi P. University of Zimbabwe Publication. Zimbabwe. Pp41.

Kwaramba, P.K. (1997). The Impact of HIV/AIDS on Zimbabwean Communal Agriculture Report for FAO, FAO Zimbabwe Publications, Harare.

Maramanyika, T., Mutekwa, T., Matsa, M. and Mapuranga, J. (2008). Evaluation of the Impact of Agricultural Recovery Programmes on Communal Farming Productivity in Masvingo District, Midlands State University, Gweru.

Ncube G. (1999). The Impact of HIV/AIDS on Smallholder Agriculture Production in the Districts of Gweru and Shurugwi in Zimbabwe and the Current Recommended Sustainable Coping Strategies and Areas of Research, In AIDS and African Smallholder Agriculture, edited by $\mathrm{G}$. Mutangadura, $\mathrm{H}$. Jackson and D. Mukurazita. SAfAIDS, Harare.

Rohr, D., Mashingaidze, A.B. and Mudhara, M. (2004). The Distribution of Relief Seed and Fertilizer in Zimbabwe: Lessons derived from the 2003/04 season, FAO Zimbabwe Publications, Harare.

Rusike, J., Reardon, T., Howard, J. \& Kelly V. (1997). Developing Cereal-based Demand fro Fertilizer Among Smallholders in Southern Africa: Lessons Learnt and Implications for Other African Regions. MSU Policy Synthesis no. 30. East Lansing.

UN Secretary General's Task Force on Women, Girls and HIV/AIDS in Southern Africa, (2004). Facing the Future Together: Report of the United Nations Secretary-General's Task Force on Women, Girls and HIV/AIDS in Southern Africa

Van Lierre, M.J. (2002). HIV/AIDS and Food Security in Sub-Saharan Africa, Paper presented at the $7^{\text {th }}$ annual ECOWAS Nutrition Forum in Banjul, Gambia.

Yamano, T. \& Jayne, T. (2002). Measuring the impacts of prime-age adult death on rural households in Kenya, Department of Agricultural Economics, Michigan State University, East Lansing, Michigan.

Zimbabwe National Statistics Agency (2009). Multiple indicators monitoring survey (MIMS). United Nations Children's Fund, Zimbabwe. 
Zimbabwe Vulnerability Assessment Committee Development Centre (SIRDC) - Food and Nutrition (ZimVac) (2010). Rural Livelihoods Assessment. Co- Council (FNC). ordinated by the Scientific Industrial Research and

Cite this Article: Mutambara J and Mumaniki C (2013). Determinants of Agricultural Performance of Supported Vulnerable Households in Zimbabwe. Greener Journal of Agricultural Sciences, 3(8): 637-643, http://doi.org/10.15580/GJAS.2013.8.061213668. 